\title{
POSSIBILITY OF WASTEWATER TREATMENT USING MFC WITH Ni-Co CATALYST OF FUEL ELECTRODE
}

\author{
Paweł P. WŁODARCZYK ${ }^{1}$, Barbara WŁODARCZYK \\ Opole University, Opole, Poland
}

\begin{abstract}
One of the problems with microbial fuel cells is a low current density of those energy sources. Nonetheless, it is possible to increase the current density by using the catalyst for fuel electrode (anode) - as long as a low cost catalyst can be found. The possibility of wastewater treatment using the Ni-Co alloy as catalyst for MFC's is presented in this paper. The alloys were obtained with different concentrations of Co (15 and 50\% of Co). The increase of current density with Ni-Co catalyst is approximately $0.1 \mathrm{~mA} / \mathrm{cm}^{2}$. So, a fundamental possibility wastewater treatment using the Ni-Co alloy as catalyst for microbial fuel cells was presented.
\end{abstract}

Keywords: microbial fuel cell, wastewater treatment, catalyst, Ni-Co alloy, renewable energy sources, environment engineering.

\section{INTRODUCTION}

Today's energetic industry struggles with difficulties with producing more and more energy. Energy production is generally based on coal, crude oil, natural gas and nuclear energy. Moreover, with the increase of the standard of living, wastes production increases very much, too. Both industrial and municipal wastewater are generated.

Currently new energy sources and waste treatment methods are being researched. One of these sources is also fuel cell (FC), mainly due to their high efficiency. The fuel that is most often used for fuel FCs is hydrogen, hydrazine

\footnotetext{
${ }^{1}$ Corresponding author: Opole University, 1Faculty of Natural Sciences and Technology, Department of Process Engineering, Dmowskiego st 7-9, 45-365 Opole, Poland, e-mail: pawel.wlodarczyk@uni.opole.pl, tel.+48774016706
} 
or methanol, but new fuels are also used, e.g. crude oil, biofuel or glucose from wastewater $[2,10,28,31,39]$. For wastewater treatment different methods are used, e.g. deposit technology sewages from yeast on agricultural field or wastewater treatment with activated sludge [9, 13, 21, 25]. However, there is an opportunity to combine energy production and wastewater treatment. A device that can accomplish this task is a microbial fuel cell (MFC). In MFC's the activated sludge bacteria were used for electricity production during wastewater treatment [19]. The concept of MFC's was created by Davis and Yarbrough in the 1960's [8]. Bacteria that were identified as capable of creating electricity in fuel cells include a wealth of genera of Geobacter, Shewanella, Pseudomonas, and others $[5,6,12,15,23,24]$. So activated sludge is capable of producing electricity.

MFC's are devices that use bacteria as catalysts to oxidize organic and inorganic matter and generate current $[3,7,8,28]$. Figure 1 shows the operating principles of a MFC $[18,27]$.

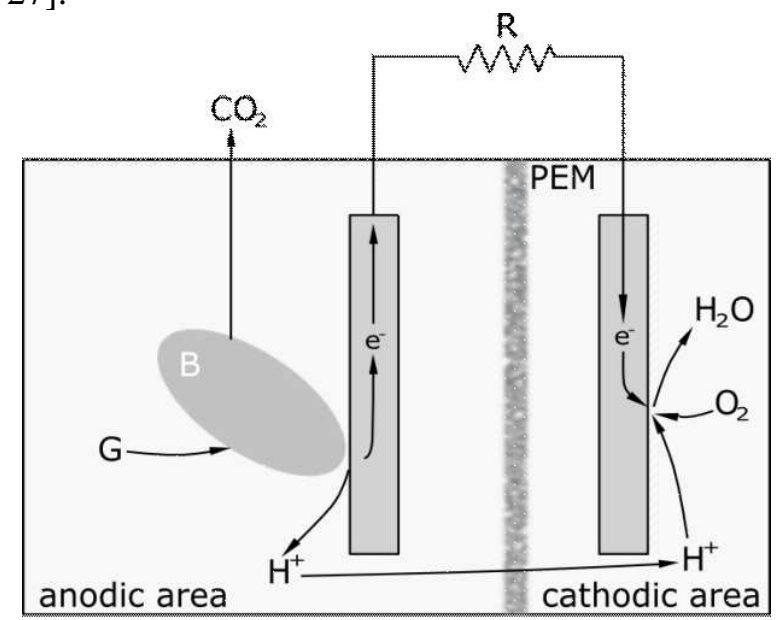

Fig. 1. Operating principles of a MFC. Figure is not to scale. PEM - proton exchange membrane, B - bacterium, G - glucose

Electrons produced by the bacteria from these substrates are transferred to the anode (negative terminal) and flow to the cathode (positive terminal) linked by a conductive material containing a resistor, or operated under a load (i.e., producing electricity that runs a device). By convention, a positive current flows from the positive to the negative terminal, a direction opposite to that of electron flow. A bacterium in the anode compartment transfers electrons obtained from an electron donor (glucose) to the anode electrode. This occurs either through direct contact, nanowires, or mobile electron shuttles. During electron production protons are also produced in excess. These protons migrate through the proton exchange membrane (PEM) into the cathode chamber. The electrons 
flow from the anode through an external resistance (or load) to the cathode where they react with the final electron acceptor (oxygen) and protons [17, 19, 27].

Graphite anodes in the shape of a brush were often used, which constituted the surface for bacterial growth and increased surface of electrode for the increase of current density (Fig.2) [15, 38].

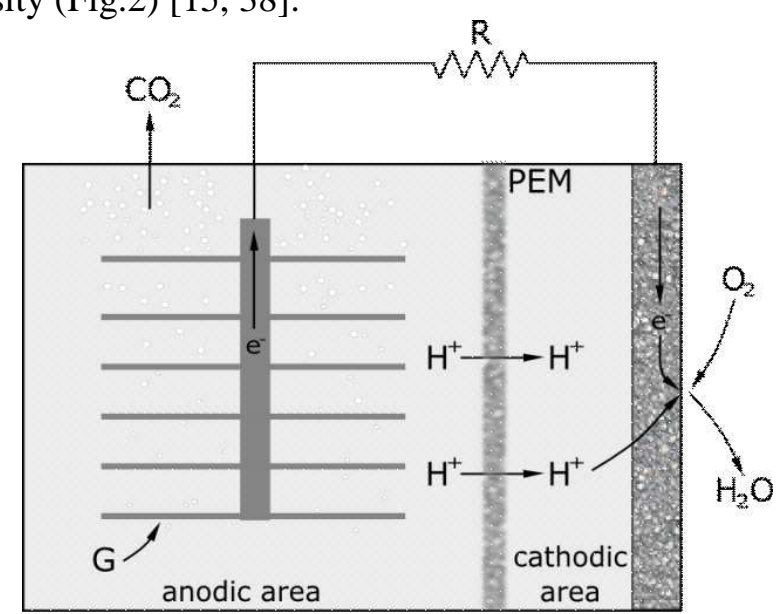

Fig. 2. Scheme of a MFC with graphite anode in the shape of brush (constituting the surface for bacterial growth). PEM - proton exchange membrane, G - glucose

Compared with hydrogen, hydrazine or methanol FC's, the current density of MFC is very low, but the hydrogen or hydrazine FC's are used as high efficiency electricity sources, and main task of MFC's is wastewater treatment.

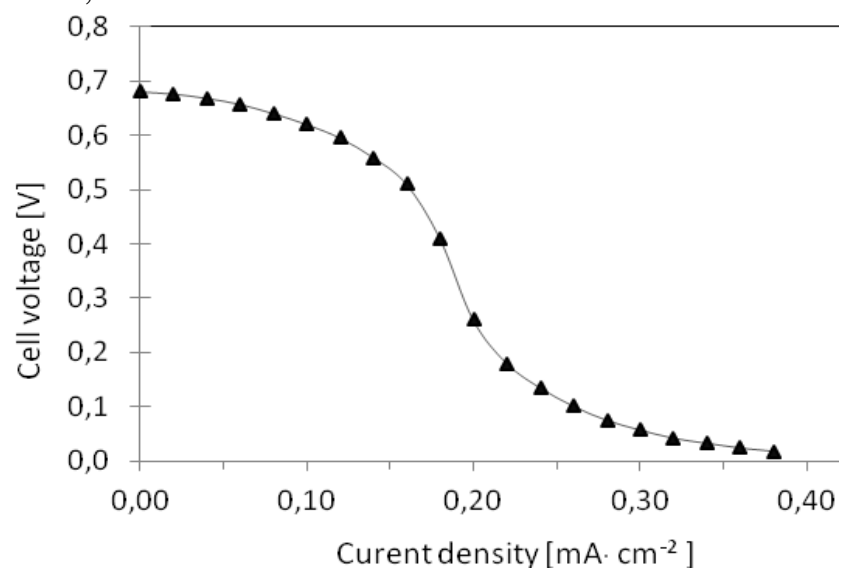

Fig. 3. Polarization curves of electrooxidation (with carbon electrode) of glucose from wastewater with bacteria from activated sludge 
The current density of MFC is lower than $1 \mathrm{~mA} / \mathrm{cm}^{2}[16,17,29,45]$. Figure 3 shows the polarization curves of electrooxidation of wastewater on carbon electrode [17, 19].

The hydrogen or hydrazine FC's are used as high efficiency electricity sources. Whereas the MFC's are only additional ecological electricity sources used during wastewater treatment. Thus, the level of current density of MFC's is not that important. In this case, important is the general possibility of obtaining electricity during wastewater treatment process.

Obviously, the increase of current density of MFC's allow for wider range of application. Therefore, every possibility for increasing the current density should be researched. One example is the selection of an appropriate catalyst for electrodes. Due to its excellent catalytic properties platinum is most commonly used as the catalyst. However, due to the high price of platinum, other catalysts that do not contain precious metals should be researched. Besides platinum, also $\mathrm{Ni}$ is frequently used as the catalyst of electrodes for fuel cells. But problems with the use of nickel impede its use. Nickel is mostly used as Raney Ni, but Raney Ni is not very easy to use. Even after reaction, Raney nickel contains significant amounts of hydrogen gas, and may spontaneously ignite when exposed to air [1]. The alloy that could be used as a catalyst in the MFC is NiCo alloy. Compared to nickel, e.g. Raney $\mathrm{Ni}$, Ni-Co alloy is not too easily oxidizable and thus it is easier to use.

In MFC organic material is oxidized on anode, and the product of oxidation is $\mathrm{CO}_{2}$ and electrons. For glucose the following reactions was obtained [15, 17, 26]

$$
\begin{gathered}
\text { ANODE } \mathrm{C}_{6} \mathrm{H}_{12} \mathrm{O}_{6}+6 \mathrm{H}_{2} \mathrm{O} \rightarrow 6 \mathrm{CO}_{2}+24 \mathrm{H}^{+}+24 e^{-} \\
\text {CATHODE } 24 \mathrm{H}^{+}+24 e^{-}+6 \mathrm{O}_{2} \rightarrow 12 \mathrm{H}_{2} \mathrm{O}
\end{gathered}
$$

Summary reaction:

$$
\mathrm{C}_{6} \mathrm{H}_{12} \mathrm{O}_{6}+6 \mathrm{O}_{2} \rightarrow 6 \mathrm{CO}_{2}+6 \mathrm{H}_{2} \mathrm{O}+\text { electricity }
$$

In MFC's carbon is most often used as the electrode (so, also as the catalyst). Acetic acid is also quite often used as catalyst. But except for acetic acid or carbon, it is also possible to use metal catalysts. Due to the excellent catalytic properties, platinum is most commonly used as the catalyst. Nickel is also quite common. But due to the high price of platinum and problems with the use of nickel, there is a need for finding other catalysts. So, it is very important to search for new Pt-free catalysts for fuel electrodes [35, 40]. Overall efficiency of the FC depends on the performance of the fuel electrode. Therefore, the search for a catalyst of the fuel electrode is a very important issue. Selection of an appropriate catalyst for the fuel electrode will allow to develop a highly efficient energy source, which is a fuel cell. 
Besides Pt, also Ni is frequently used as the catalyst of electrodes for fuel cells. But problems with the use of Ni impede its use. Nickel is mostly used as Raney $\mathrm{Ni}$, but Raney $\mathrm{Ni}$ is not very easy to use [1]. The new catalysts allow for the elimination of costly platinum and difficulties with the use of nickel [30, 32]. The efficiency of FC anf MFC $\eta_{F C}$ is defined to be:

$$
\eta_{F C}=1-\frac{T \cdot \Delta G}{\Delta H}
$$

where:

$$
\begin{aligned}
& \Delta G \text { - the change in Gibbs free energy }[\mathrm{kJ} / \mathrm{mol}], \\
& \Delta H \text { - the change in enthalpy }[\mathrm{J} / \mathrm{kg}], \\
& T \text { - the absolute temperature }[\mathrm{K}]
\end{aligned}
$$

The equation (2.4) shows that the efficiency of the cell depends on the magnitude and sign of entropy. From the equation it can be seen that if for the reaction in a fuel cell $\Delta H>0$ and $\Delta S>0$, then thermodynamic factor of efficiency $\eta<1$ and it decreases with the increase of the temperature [22, 33]. But under real conditions the efficiency of FC and MFC is always lower than theoretical efficiency. In a fuel cell the maximum energy of chemical conversion of energy into work is equal to the free energy reaction $(2.5)[9,37]$

$$
\Delta G=\Delta H-T \Delta S
$$

where:

$\Delta S$ - the change in entropy $[\mathrm{J} / \mathrm{K}]$,

Changing the Gibbs free energy $\Delta G$ associated with the cell electromotive force $E^{\circ}$ is represented by the relation:

$$
\Delta G=-n F E^{\circ}
$$

where:

$n$ - the number of electrons involved in the electrode reaction,

$F$ - the Faraday constant per volt gram equivalent $[\mathrm{kJ}]$,

$F$ - the $E^{\circ}$ electromotive force [V].

In the case of a real cell the equation can be written as [4, 22, 34]

$$
\Delta G^{\prime}=-(n F)^{\prime} E
$$

where:

$(n F)^{\prime}$ - the real amount of energy obtained from one mole of fuel $[\mathrm{kJ}]$. 
Under real conditions the following relationship always occurs

$$
\Delta G^{\prime}<\Delta G
$$

So, under real conditions the efficiency of FC and MFC is always lower than theoretical efficiency.

The current density is most important parameter of FC and important parameter of MFC [4, 17, 37]. So, it is important to search a new catalysts to assurance adequate current density of electrooxidation of glucose.

Activation barriers impede the conversion of reactants to products. So part of the cell voltage is used for the reduction in the activation barrier. These losses are called the overpotential $\eta_{a c t}$.

The correlation between current density and overpotential is described by the Butler-Volmer exponential function [4]:

$$
i=i_{0} \cdot e^{K \cdot \eta_{a c t}}
$$

where:

$i_{0}$ - the exchange current density $\left[\mathrm{mA} / \mathrm{m}^{2}\right]$,

$\eta_{\text {act }}$ - the activation overpotential [V],

$K$ - the factor of dependence of activation overpotential on reaction speed.

Unfortunately, despite extensive knowledge in the field of solid-state physics and kinetics of catalytic reactions, the selection of the catalysts is carried out mainly experimentally.

One of the important factors affecting the work of the MFC is also the temperature. Temperature has a significant impact on work of the MFC for two reasons. First, the result from the relation (2.9) and this influence is related to the functioning of the microbes, which need specific conditions for development. However, the temperature influence on current density of the MFC can be very different $[11,14]$. So, it is necessary to perform measurements of wastewater electrooxidation with new catalysts [40, 42]. For egsample with $\mathrm{Ni}-\mathrm{Co}$ for MFC's and influence of temperature on work of MFC'c with Ni-Co catalyst.

\section{MATERIAL AND METHODS}

$\mathrm{Ni}$-Co alloys were obtained by the method of electrochemical deposition. The alloys were deposited on smooth surface of copper electrode. The alloys were deposited on copper electrode from a mixture of $\mathrm{NiSO}_{4}, \mathrm{CoSO}_{4}, \mathrm{CoCl}_{2}$ and $\mathrm{H}_{3} \mathrm{BO}_{3}$ (Table 1). 
Table 1. Mixture composition for deposited Ni-Co alloy on copper electrode

\begin{tabular}{|c|c|c|c|c|c|}
\hline component & $\begin{array}{c}\text { volume } \\
{[\mathrm{g} / \mathrm{l}]}\end{array}$ & $\mathrm{pH}$ & $\begin{array}{c}\text { temperature } \\
{[\mathrm{K}]}\end{array}$ & $\begin{array}{c}\text { current } \\
\text { density } \\
{\left[\mathrm{A} / \mathrm{dm}^{2}\right]}\end{array}$ & $\begin{array}{c}\text { concentration } \\
\text { of Co [\%] }\end{array}$ \\
\hline $\begin{array}{c}\mathrm{NiSO}_{4} \times 7 \mathrm{H}_{2} \mathrm{O} \\
\mathrm{CoCl}_{2} \times 6 \mathrm{H}_{2} \mathrm{O} \\
\mathrm{H}_{3} \mathrm{BO}_{3}\end{array}$ & $\begin{array}{c}260 \\
14\end{array}$ & 3.0 & 293 & 1.6 & 15 \\
\hline $\mathrm{NiSO}_{4} \times 7 \mathrm{H}_{2} \mathrm{O}$ & 195 & 2.0 & 293 & 3.0 & 50 \\
$\mathrm{CoSO}_{4} \times 7 \mathrm{H}_{2} \mathrm{O}$ & 35 & & & & \\
\hline
\end{tabular}

Before the deposition of the alloy, copper electrode was prepared in several steps $[43,44]$ :

- surface was mechanically purified to a shine,

- surface was degreased in $25 \%$ aqueous solution of $\mathrm{KOH}$ (after degreasing, the surface shall be completely wettable with water),

- electrode was digested in acetic acid,

- electrode was washed with alcohol.

The alloys were obtained with different concentrations of $\mathrm{Ni}$ and $\mathrm{Co}$ (15 and $50 \%$ of $\mathrm{Co}$ ). Concentrations $15 \%$ of Co was chosen due to the maintenance of highest amounts of nickel in alloy. Concentrations $50 \%$ of Co was chosen due to the comparison of catalytic properties of $\mathrm{Ni}-\mathrm{Co}$ alloy with low and high concentarion of Co. The time of the deposition was equal to 1 hour. The chemical composition of Ni-Co alloys was determined with the XRD method.

Researches were done by the method of polarizing curves of electrooxidation of wastewater with activated sludge bacteria. The researches were done in a glass vessel, on a carbon and copper electrode with $\mathrm{Ni}-\mathrm{Co}$ alloy as the catalyst. Measurements were done in a glass cell with the AMEL System 5000 potentiostat connected with computer for data recording. First the electrooxidation on carbon electrode was conducted and then measurements were performed for the electrooxidation with a Ni-Co catalyst. Researches for Ni-Co alloy as catalyst were done for selected alloys (containing 15\% and 50\% of Co), at the temperature of 293, 295, 297, 299, 301 and $303 \mathrm{~K}$ are presented in this paper.

Before each measurement of electrooxidation of activated sludge wastewater $\mathrm{pH}$ was measured with the CyberScan $2000 \mathrm{pH}$-meter, while the conductivity was measured with the use of AquaPro AP-2 conductivity meter. Measurements were made at the temperature of $293 \mathrm{~K}$ [40]. 


\section{RESULTS}

In the first stage, the electrooxidation on carbon electrode was conducted and then measurements were performed for the electrooxidation with Ni-Co catalyst. The measurements allowed to evaluate the influence of the Ni-Co alloy used as catalyst on change of current density $i$.

Conductivity of the wastewater (after initial treatment) with activated sludge was equal to $1.716 \mathrm{mS}$, and $\mathrm{pH}$ was equal to 7.6.

Figures 4-9 show the polarization curves of wastewater electrooxidation on carbon and Ni-Co alloy electrode with activated sludge bacteria at the temperature of 293-303 K.

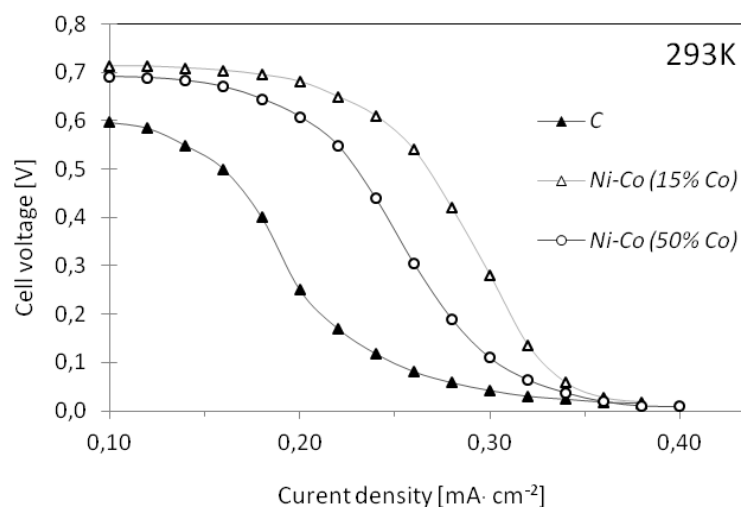

Fig. 4. Polarization curves of electrooxidation of wastewater with bacteria from activated sludge with carbon and Ni-Co alloy catalyst at the temperature of $293 \mathrm{~K}$

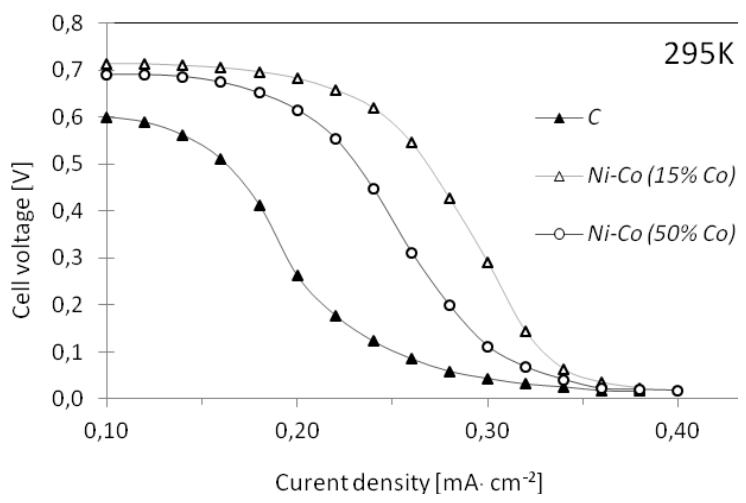

Fig. 5. Polarization curves of electrooxidation of wastewater with bacteria from activated sludge with carbon and Ni-Co alloy catalyst at the temperature of $295 \mathrm{~K}$ 


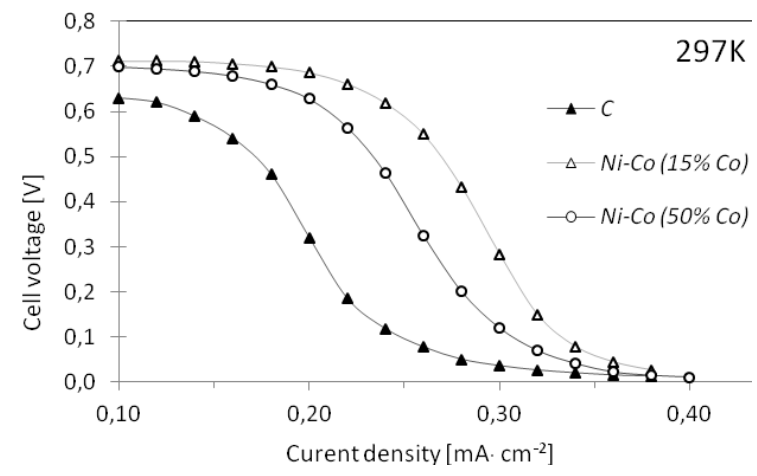

Fig. 6. Polarization curves of electrooxidation of wastewater with bacteria from activated sludge with carbon and Ni-Co alloy catalyst at the temperature of $297 \mathrm{~K}$

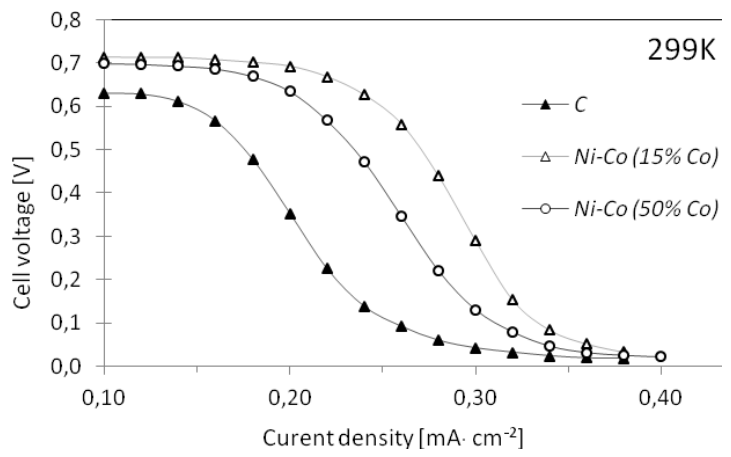

Fig. 7. Polarization curves of electrooxidation of wastewater with bacteria from activated sludge with carbon and Ni-Co alloy catalyst at the temperature of $299 \mathrm{~K}$

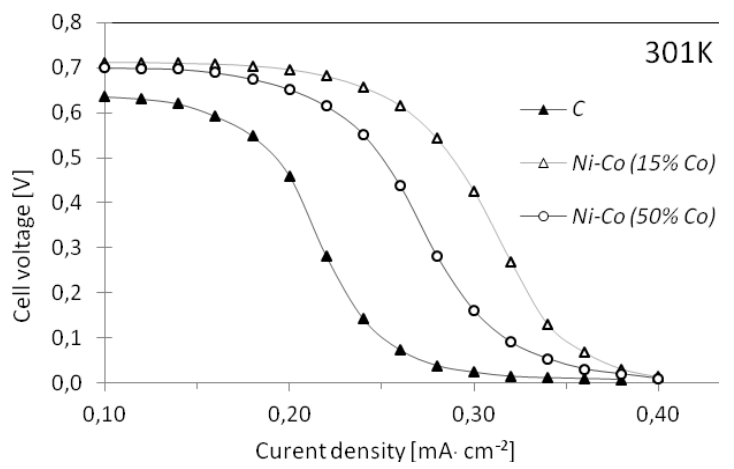

Fig. 8. Polarization curves of electrooxidation of wastewater with bacteria from activated sludge with carbon and Ni-Co alloy catalyst at the temperature of $301 \mathrm{~K}$ 


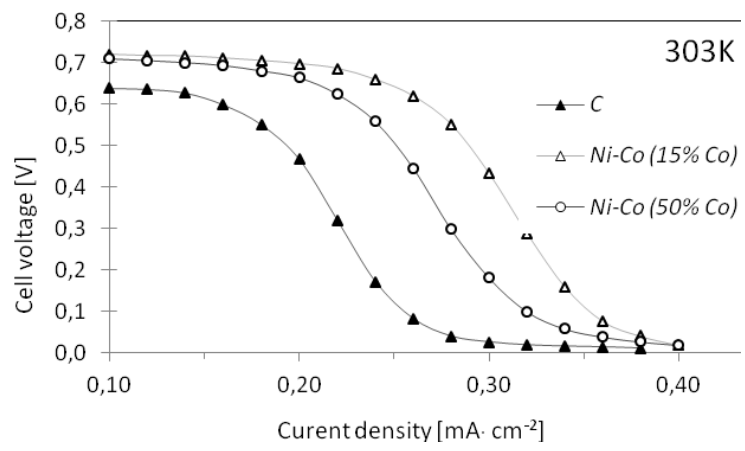

Fig. 9. Polarization curves of electrooxidation of wastewater with bacteria from activated sludge with carbon and Ni-Co alloy catalyst at the temperature of $303 \mathrm{~K}$

In any case (for all temperatures), for the Ni-Co alloy the obtained current density was higher than for the carbon electrode.

\section{DISCUSSION AND CONCLUSIONS}

The measurements for the electrode with Ni-Co alloy as catalyst showed an increase of current density compared to the measurements for the carbon electrode. Polarization curve at the temperature of 293K (Fig. 4) shows that current density for carbon electrode is about $0.19 \mathrm{~mA} / \mathrm{cm}^{2}$. Polarization curves for Ni-Co alloy $(15 \% \mathrm{Co})$ as catalyst allow for the increase of current density up to $0.30 \mathrm{~mA} / \mathrm{cm}^{2}$. Increase of Co concentration to $50 \%$ concentration of Co the current density is higher only by $0.7 \mathrm{~mA} / \mathrm{cm}^{2}$, compared to current density obtained during electrooxidation with a carbon electrode.

Polarization curve at the temperature of $295 \mathrm{~K}$ (Fig. 5) shows that current density for carbon electrode is about $0.21 \mathrm{~mA} / \mathrm{cm}^{2}$. Polarization curves for Ni-Co alloy $(15 \% \mathrm{Co})$ as catalyst allow for the increase of current density up to 0.31 $\mathrm{mA} / \mathrm{cm}^{2}$. Increase of Co concentration to $50 \%$ concentration of Co the current density is higher only by $0.6 \mathrm{~mA} / \mathrm{cm}^{2}$, compared to current density obtained during electrooxidation with a carbon electrode.

Polarization curve at the temperature of $297 \mathrm{~K}$ (Fig. 6) shows that current density for a carbon electrode is about $0.20 \mathrm{~mA} / \mathrm{cm}^{2}$. Polarization curves for $15 \% \mathrm{Co}$ allow for the increase of current density up to $0.30 \mathrm{~mA} / \mathrm{cm}^{2}$, just like at the temperature of $293 \mathrm{~K}$. The current density of $50 \%$ concentration of Co the current density is higher only by $0.6 \mathrm{~mA} / \mathrm{cm}^{2}$, compared to the current density obtained during electrooxidation with a carbon electrode. 
Polarization curve at the temperature of $299 \mathrm{~K}$ (Fig. 7) shows that current density for a carbon electrode is about $0.19 \mathrm{~mA} / \mathrm{cm}^{2}$. Polarization curves for $15 \% \mathrm{Co}$ allow for the increase of current density up to $0.31 \mathrm{~mA} / \mathrm{cm}^{2}$, just like at the temperature of 293 and $295 \mathrm{~K}$. The current density of $50 \%$ concentration of Co the current density is higher only by $0.7 \mathrm{~mA} / \mathrm{cm}^{2}$, compared to the current density obtained during electrooxidation with a carbon electrode.

Polarization curve at the temperature of $201 \mathrm{~K}$ (Fig. 8) shows that current density for a carbon electrode is about $0.21 \mathrm{~mA} / \mathrm{cm}^{2}$. Polarization curves for $15 \% \mathrm{Co}$ allow for the increase of current density up to $0.29 \mathrm{~mA} / \mathrm{cm}^{2}$, just like at the temperature of 293 and $295 \mathrm{~K}$. The current density of $50 \%$ concentration of Co the current density is higher only by $0.5 \mathrm{~mA} / \mathrm{cm}^{2}$, compared to the current density obtained during electrooxidation with a carbon electrode.

Polarization curve at the temperature of $303 \mathrm{~K}$ (Fig. 9) shows that current density for a carbon electrode is about $0.22 \mathrm{~mA} / \mathrm{cm}^{2}$. So, the temperature increase of $10 \mathrm{~K}$ (from $293 \mathrm{~K}$ to $303 \mathrm{~K}$ ) increases the current density by $10 \%$. Polarization curves for $15 \%$ Co allow for the increase of current density up to $0.33 \mathrm{~mA} / \mathrm{cm}^{2}$. At $50 \%$ concentration of Co the current density is higher only by $0.6 \mathrm{~mA} / \mathrm{cm}^{2}$, compared to the current density obtained during electrooxidation with a carbon electrode.

In any case (for all temperatures), for the Ni-Co alloy the obtained current density was higher than for the carbon electrode. However, those current density changes are not significant - approx. by $0.1 \mathrm{~mA} / \mathrm{cm}^{2}$ (15\% Co). But those changes are $50 \%$ for Ni-Co alloy with $15 \%$ Co, compared to the use of a carbon electrode.

High capacity of Ni-Co alloy with $15 \%$ Co is the result of the high Ni content. Increasing the cobalt content to $50 \%$ causes a significant reduction in current density for all temperatures (293-303K).

The MFC's are a low-density power sources. One of the reasons of low current density is the low electrical conductivity of wastewater. But electrical power generation in MFC's is just an additional process during purification of wastewater. So, increase of power density with Ni-Co alloy used as the catalyst allow to develop green energy sources.

A fundamental possibility wastewater treatment using the Ni-Co alloy as catalyst for MFC's was presented in this paper. Subsequent research should include MFC's operation measurements in real conditions. However, it should be measured how the activated sludge microorganisms develop in the presence of Ni-Co alloy . 


\section{REFERENCES}

1. Armour M-A., Hazarodous laboratory chemicals disposal guide, CRC Press, 2003.

2. Asazawa K., Yamada K., Tanaka H., Oka A., Taniguchi M., Kobayashi T., A Platinum-Free Zero-Carbon-Emission Easy Fuelling Direct Hydrazine Fuel Cell for Vehicles, Angewandte Chemie, 119 (42) (2007) 8170-8173.

3. Berk R.S., Canfield J.H., Bioelectrochemical energy conversion, Applied and Environmental Microbiology, 12 (1964) 10-12.

4. Bockris J.O’M., Reddy A.K.N., Modern Electrochemistry, Kulwer Academic/Plenum Publishers, New York, 2000.

5. Bond D. R., Lovley D. R., Electricity production by Geobacter sulfurreducens attached to electrodes, Applied and Environmental Microbiology, 69 (2003) 1548-1555.

6. Chaudhuri S.K., Lovley D.R., Electricity generation by direct oxidation of glucose in mediatorless microbial fuel cells, Nature Biotechnology, 21 (2003) 1229-1232.

7. Cohen B., The bacterial culture as an electrical half-cell, Journal of Bacteriology, 21 (1931) 18-19.

8. Davis J.B., Yarbrough H.F., Preliminary experiments on a microbial fuel cell, Science, 137 (1962) 615-616.

9. Grady C.P.L., Daigger G.T., Love N.G., Filipe C.D.M., Biological Wastewater Treatment: Third Edition, IWA Publishing (Co-Published with CRC Press), 2011.

10. Hamnett A., Mechanism and electrocatalysis in the direct methanol fuel cell, Catalysis Today, 38 (4) (1997) 445-457.

11. Jadhav G.S., Ghangrekar M.M., Performance of microbial fuel cell subjected to variation in $\mathrm{pH}$, temperature, external load and substrate concentration, Bioresource Technology, 100 (2) 2009) 717-723.

12. Kim H.J., Park H.S., Hyun M.S., Chang I.S., Kim M., Kim B.H., A mediator-less microbial fuel cell using a metal reducing bacterium, Shewanella putrefacians, Enzyme and Microbial Technology, 30 (2002) 145-152.

13. Kutera J., Use of wastewater from yeast factory, Scientific Papers of the Agricultural University of Wroclaw, 1996.

14. Liu H., Grot S., Logan B.E., Electrochemically Assisted Microbial Production of Hydrogen from Acetate, Environmental Science \& Technology, 39 (11) (2005) 4317-4320. 
15. Liu H., Ramnarayanan R., Logan B.E., Production of electricity during wastewater treatment using a single chamber microbial fuel cell, Environmental Science \& Technology, 38 (2004) 2281-2285.

16. Liu Y., Harnisch F., Fricke K., Sietmann R., Schröder U., Improvement of the anodic bioelectrocatalytic activity of mixed culture biofilms by a simple consecutive electrochemical selection procedure, Biosensors and Bioelectronics, 24 (1) (2008) 1006-1011.

17. Logan B.E., Microbial fuel cell, Wiley \& Sons (2008).

18. Logan B.E., Hamelers B., Rozendal R., Schroder U., Keller J., Verstraete W., Rabaey K., Microbial Fuel Cells: $\square$ Methodology and Technology, Environmental Science \& Technology, 40 (17) (2006) 5181-5192.

19. Logan B.E., Regan J.M., Electricity - producing bacterial communities in microbial fuel cells, Trends Microbiol., 14 (2006) 512-518.

20. Milewski J., Lewandowski J., Biofuels as fuels for high temperature fuel cells, Journal of Power Technologies, 93 (5) (2013) 347-353.

21. Nowak A.J., Królik D., Kostecki J., Wastewater treatment in constructed wetlands, Civil and Environmental Engineering Reports, 11 (2013) 93-99.

22. O'Hayre R., Cha S-W., Colella W., Prinz F.B., Fuel Cell Fundamentals, John Wiley \& Sons, 2005.

23. Park H.S., Kim B.H., Kim H.S., Kim H.J., Kim G.T., Kim M., Chang I.S., Park Y.K., Chang H.I., A novel electrochemically active and $\mathrm{Fe}(\mathrm{III})$ reducing bacterium phylogenetically related to Clostridium butyricum isolated from a microbial fuel cell, Anaerobe, 7 (2001) 297-306

24. Pham C.A., Jung S.J., Phung N.T., Lee J., Chang I.S., Kim B.H., Yi H., Chun J., A novel electrochemically active and Fe(III)-reducing bacterium phylogenetically related to Aeromonas hydrophila, isolated from a microbial fuel cell, FEMS Microbiology Letters, 223 (2003) 129-134.

25. Płuciennik-Koropczuk E., Sadecka Z., Myszograj S., COD fractions in raw and mechanically treated wastewater, Civil and Environmental Engineering Reports, 11 (2013) 101-113.

26. Rabaey K., Alterman P., Clauwaert P., De Schamphelaire L., Boon N., Verstraete W., Microbial fuel cells in relation to conventional anaerobic digestion technology, Engineering in Life Science, 6 (2006) 285-292.

27. Rabaey K., Verstraete W., Microbial fuel cells: novel biotechnology for energy generation, Trends in Biotechnology, 23 (2005) 291-298

28. Rao J.R., Richter G.J., Von Sturm F., Weidlich E., The performance of glucose electrodes and the characteristics of different biofuel cell constructions, Bioelectrochem, Bioenerg., 3 (1976) 139-150.

29. Ringeisen B.R., Henderson E., Wu P.K., Pietron J., Ray R., Little B., Biffinger J.C., Jones-Meehan J.M., High Power Density from a Miniature 
Microbial Fuel Cell Using Shewanella oneidensis DSP10, Environmental Science \& Technology, 40 (2006) 2629-2634.

30. Rolison D.R., Hagans P.L., Swider K.E., Long J.W., Role of Hydrous Ruthenium Oxide in Pt-Ru Direct Methanol Fuel Cell Anode Electrocatalysts: $\square$ The Importance of Mixed Electron/Proton Conductivity, Langmuir, 15 (3) (1999) 774-779.

31. Serov A., Kwak C., Direct hydrazine fuel cells, Applied Catalysis B: Environmental, 98 1-2 (2010) 1-9.

32. Steigerwalt E.S., Deluga G.A., Cliffel D.E., Lukehart C.M., A PtRu/graphitic carbon nanofiber nanocomposite exhibiting high relative performance as a direct-methanol fuel cell anode catalyst, The Journal of Physical Chemistry B, 105 (34) (2001) 8097-8101.

33. Springer T.E., Wilson M.S., Gottesfield S., Modeling and Experimental Diagnostics in Polymer Electrolyte Fuel Cells, Journal of The Electrochemical Society, 140 (1993) 3513-3526.

34. Stolten D., Hydrogen and Fuel Cells. Fundamentals, Technologies and Applications, Wiley-VCH, 2010.

35. Twigg M.V., Catalyst Handbook, Wolfe Publishing Ltd., 1989.

36. Vetter K., Electrochemical kinetics, Springer-Verlag, Berlin-GottingenHeidelberg, (1961).

37. Vielstich W., Fuel cell, Wiley Interscience, 1970.

38. Wang X., Feng Y.J., Lee H., Electricity production from beer brewery wastewater using single chamber microbial fuel cell. Water Science \& Technology, 57 (2008) 1117-1121.

39. Włodarczyk B., Włodarczyk P.P., Electricity production in microbial fuel cell with $\mathrm{Cu}-\mathrm{B}$ alloy as catalyst of anode, QUAESTI 2015, Civil engineering (2015) 305-308. DOI 10.18638/quaesti.2015.3.1.211

40. Włodarczyk B., Włodarczyk P.P., Porównanie skuteczności elektroutleniania $\mathrm{w}$ mikrobiologicznym ogniwie paliwowym $\mathrm{z}$ katalizatorem stalowym i napowietrzania w oczyszczaniu ścieków, Inżynieria i Ochrona Środowiska, 18 (2) (2015) 189-198.

41. Włodarczyk P.P., Włodarczyk B., Powering fuel cells with crude oil, Journal of Power Technologies, 93 (5) (2013) 394-397.

42. Włodarczyk, P.P., Włodarczyk, B., Analysis of the possibility of using stainless steel and copper boride alloy as catalyst for microbial fuel cell fuel electrode, Archiwum Gospodarki Odpadami i Ochrony Środowiska, 17 (1) (2015) 111-118.

43. Włodarczyk, P.P., Włodarczyk, B., Possibility of using Ni-Co alloy as catalyst for oxygen electrode of fuel cell, Chinese Business Review, 14 (3) (2015) 159-167. DOI: 10.17265/1537-1506/2015.03.005 
44. Włodarczyk, P.P., Włodarczyk, B., Ni-Co alloy as catalyst for fuel electrode of hydrazine fuel cell, China-USA Business Review, 14 (5) (2015) 269-279. DOI: $10.17265 / 1537-1514 / 2015.05 .005$

45. Zhao F., Sladea R.C.T., Varcoea J.R., Techniques for the study and development of microbial fuel cells: an electrochemical perspective, Chemical Society Reviews, 38 (2009) 1926-1939.

\section{MOŻLIWOŚĆ OCZYSZCZANIA ŚCIEKÓW PRZY WYKORZYSTANIU MIKROBIOLOGICZNEGO OGNIWA PALIWOWEGO Z NIKLOWO- KOBALTOWYM KATALIZATOREM ELEKTRODY PALIWOWEJ}

\section{Streszczenie}

Jednym z ograniczeń w zastosowaniu mikrobiologicznych ogniw paliwowych jest niska gęstość prądu. Istnieje jednak możliwość podwyższenia tej wartości wykorzystując innego rodzaju katalizator elektrody paliwowej. Praca przedstawia możliwość oczyszczania ścieków za pomocą mikrobiologicznego ogniwa paliwowego z wykorzystaniem stopu Ni-Co jako katalizatora elektrody paliwowej. Do badań wykorzystano stopy Ni-Co o różnej koncentracji kobaltu (15 i 50\%). Wykorzystując analizowany katalizator uzyskano wzrost gęstości prądu rzędu $0,1 \mathrm{~mA} / \mathrm{cm}^{2}$. Wykazano, więc możliwość wykorzystania stopu Ni-Co jako katalizatora mikrobiologicznego ogniwa paliwowego.

Słowa kluczowe: mikrobiologiczne ogniwa paliwowe, oczyszczanie ścieków, katalizator, stop Ni-Co, odnawialne źródła energii, inżynieria środowiska.

Editor received the manuscript: 30.06 .2015 